\title{
Parathyroid hormone-related protein of malignancy: Immunohistochemical and biochemical studies in normocalcaemic and hypercalcaemic patients with cancer
}

\author{
S H Ralston, J Danks, J Hayman, W D Fraser, C S Stewart, T J Martin
}

\begin{abstract}
Immunohistochemical staining for parathyroid hormone-related protein was performed in 27 tumours from 19 normocalcaemic and eight hypercalcaemic patients with cancer. All the tumours from hypercalcaemic patients stained positively for the protein, as did 17 tumours from normocalcaemic patients. Only hypercalcaemic patients had biochemical evidence of increased bone resorption and abnormalities of renal tubular reabsorption of calcium and phosphate, consistent with the presence of parathyroid hormonerelated protein. While tumour mass was higher in hypercalcaemic patients, only one of the initially normocalcaemic patients with positively staining tumours subsequently went on to develop hypercalcaemia and more advanced disease.

These data confirm the importance of parathyroid hormone-related protein as a mediator of humoral hypercalcaemia in patients with solid tumours and suggest that low tumour mass may be one reason why serum calcium values are not increased in all patients with tumours containing parathyroid hormone-related protein. None the less normocalcaemia, despite tumour progression in patients whose tumours stained positively for parathyroid hormone-related protein, suggests that other factors may also be important, such as differences in the rate of secretion of the protein by different tumours, or the production of different forms of parathyroid hormone-related protein with varying biological effects.
\end{abstract}

Parathyroid hormone-related protein has been implicated as an important mediator of humoral hypercalcaemia in malignancy. ${ }^{1-3}$ Because of its homology with parathyroid hormone (PTH) at the amino-terminus, ${ }^{45}$ parathyroid hormone-related protein mimics much of the behaviour of PTH on bone and kidney $^{6-8}$ and so reproduces the "hyperparathyroid-like" biochemical abnormalities which are typical of hypercalcaemia associated with cancer. . $^{-11}$ In previous studies parathyroid hormone-related protein and its messenger RNA were shown in tumour tissue from both normocalcaemic and hypercalcaemic cancer patients using immunohistochemical techniques, ${ }^{12}$ Northern blot analysis, ${ }^{13}$ and in situ hybridisation. ${ }^{14}$ In addition to its role as a mediator of hypercalcaemia in malignancy, parathyroid hormone-related protein has also been suggested as an important calcium regulator in the fetus, ${ }^{1516}$ and it has been shown in adult parathyroid adenomas and hyperplasia. ${ }^{17}$ Many normal tissues also express parathyroid hormone-related protein, including lactating mammary gland, ${ }^{18}$ keratinocytes, ${ }^{19}$ fibroblasts, brain, various endocrine tissues and gastric mucosa. ${ }^{20}$

It is at present unclear why only a proportion of patients with tumours that produce parathyroid hormone-related protein are hypercalcaemic, given the potent bone resorbing and calcium increasing effects of parathyroid hormone-related protein in vivo and in vitro..$^{6-8}$ Various reasons have been suggested, including failure of parathyroid hormone-related protein translation from its messenger RNA, ${ }^{14}$ low levels of protein secretion, low tumour mass, ${ }^{1}$ concomitant secretion of other bone resorbing factors which act synergistically with parathyroid hormonerelated protein to cause hypercalcaemia, ${ }^{21}$ and the ability of homeostatic mechanisms to preserve normocalcaemia despite the release of the protein. ${ }^{14}$

To investigate further the association between the presence of parathyroid hormone-related protein in tumours and the development of hypercalcaemia, we carried out immunohistochemical staining for parathyroid hormone-related protein in a series of tumours from normocalcaemic and hypercalcaemic patients with cancer who also were evaluated biochemically for evidence of the protein's effects on bone and kidney.

\section{Methods}

Tumour tissue was available from 27 patients as the result of procedures performed during the course of routine management and provided that informed consent to participating in the study had been given. Eight patients were hypercalcaemic at the time of study (serum calcium adjusted for albumin of $2.70 \mathrm{mmol} / \mathrm{l}$ or greater) and 19 were normocalcaemic. Eleven of the patients who were initially normocalcaemic were subsequently 
followed up by regular checks of serum calcium until just before death; three of these patients developed hypercalcaemia and eight remained normocalcaemic. In the remaining eight normocalcaemic patients no further measurements of serum calcium were available, either because the patients were lost to follow up $(n=5)$, or because they died of early complications after surgical resection of lung tumours $(\mathrm{n}=3$; arrhythmia $\mathrm{n}=1$, pulmonary embolus $n=1$; pneumonia $n=1$ ).

Immunohistochemical staining for parathyroid hormone-related protein was performed on formalin fixed, paraffin wax embedded sections. The antiserum used for immunostaining was prepared in New Zealand white rabbits immunised against synthetic parathyroid hormone-related protein (1-34) as described previously. ${ }^{12}$ This antiserum has been fully characterised in previous studies $^{121517}$ and is specific to the (1-34) portion of the parathyroid hormone-related protein molecule; it shows no cross reactivity with PTH or PTH-derived peptides in Western blots, or at high concentrations in blocking biological activity.

A positive control was included in every experiment consisting of a squamous carcinoma of the skin. ${ }^{12}$ Standard negative controls for method and antibody were used as previously described, ${ }^{12}{ }^{17}$ including alternating deletions of the antibody layers, primary antiserum, second antibody and peroxidaseantiperoxidase complex; and substitution of non-immune and unrelated immune rabbit serum for primary antiserum and preabsorption of the antibody overnight with parathyroid hormone-related protein $(1-34)$ or PTH (1-34) peptides. All of these controls abolished staining, except for the overnight preabsorption with PTH (1-34) which had no effect.

In all patient samples the pattern of parathyroid hormone-related protein staining was graded blind by an observer on a three point scale: $0=$ no staining (negative); definite staining of cytoplasm of cells (positive); dark staining of cytoplasm (strongly positive).

Assessment of tumour mass at the time when the tissue samples were obtained was achieved by a combination of direct measurement of the dimensions of excised tumour specimens or by the appearances on computed tomography scans; for the purposes of this study the tumours were assumed to be perfect spheres, with a volume given by the equation $\left(\frac{\pi \mathrm{d}^{3}}{6}\right)$, where $\pi=3.141$ and $\mathrm{d}=$ maximum diameter of the tumour.

Biochemical analyses were made using standard autoanalyser techniques (Technicon, Tarrytown, USA) on blood samples and second-voided urine samples obtained after an overnight fast. Total serum calcium was adjusted for albumin as previously described (reference range $2 \cdot 2-2 \cdot 6 \mathrm{mmol} / \mathrm{l}$ ). ${ }^{22}$ Plasma intact PTH (1-84) concentrations were measured using a two-site immunoradiometric assay ${ }^{22}$ (reference range 1.0-5.0 pmol/l). Urine cyclic adenosine mono- phosphate (cAMP) was measured using a radioimmunoassay as previously described. ${ }^{22}$ The following derived variables were calculated from fasting blood and urine measurements: molar urinary ratios of calcium to creatinine (reference range $=<0.50$ ); hydroxyproline to creatinine (reference range $=<0.030)$; and cyclic AMP to creatinine (reference range $=0 \cdot 1-0 \cdot 65$ ). Renal tubular reabsorption of phosphate (reference range $0 \cdot 80-1 \cdot 35$ ) was derived from a nomogram ${ }^{23}$ and renal tubular reabsorption of calcium, corrected for urinary sodium excretion (reference range $1.98-2.76$ ) by the method of Need $e t a l) .{ }^{24}$

Student's $t$ test was used for statistical analysis.

\section{Results}

Relevant clinical and biochemical details are shown in table 1 for normocalcaemic and hypercalcaemic subgroups (serum calcium less than or equal to and greater than $2 \cdot 70 \mathrm{mmol} / 1$, respectively). The hypercalcaemic patients had significantly lower serum phosphate, renal tubular reabsorption of phosphate values, and higher hydroxyproline:creatine, calcium: creatine ratios and renal tubular reabsorption of calcium, corrected for urinary sodium excretion, values than the normocalcaemic patients. Cyclic AMP:creatine values were also higher in the hypercalcaemic patients, but the difference between the groups was not significant. Four of the normocalcaemic patients had increased cyclic AMP: creatine values $(0.66,0.75,0.81$, $0.97)$ and three of the hypercalcaemic patients had normal values $(0.38,0.50,0.56)$. There was no significant correlation between tumour mass (see below) and cyclic AMP:creatine values $(\mathrm{r}=0 \cdot 137, \mathrm{p}=\mathrm{NS})$. Plasma (1-84) PTH values (not shown) were undetectable in all hypercalcaemic patients and were either undetectable or lay within the low-normal range in normocalcaemic patients. The mean (SEM) tumour mass was $61.5(11.4) \mathrm{cm}^{3}$ in the normocalcaemic patients (range 1.8-179.6)

Table 1 Relevant clinical and biochemical details in study group

\begin{tabular}{|c|c|c|}
\hline & $\begin{array}{l}\text { Normocalcaemic } \\
(n=19)\end{array}$ & $\begin{array}{l}\text { Hypercalcaemic } \\
(n=8)\end{array}$ \\
\hline Serum calcium (mmol/l) & $2.53(0.01)$ & $3.07(0.08)^{\star \star \star}$ \\
\hline Serum phosphate $(\mathrm{mmol} / \mathrm{l})$ & $1.13(0.04)$ & $0.91(0.07)^{\star}$ \\
\hline Serum creatinine (umol/1) & $82(3 \cdot 6)$ & $70(7 \cdot 4)$ \\
\hline $\begin{array}{l}\text { Urinary cyclic AMP: } \\
\text { creatine (mmol/mmol) }\end{array}$ & $0.53(0.04)$ & $1.24(0.41)$ \\
\hline $\begin{array}{l}\text { Urinary calcium: creatinine } \\
(\mathrm{mmol} / \mathrm{mmol})\end{array}$ & $0.30(0.03)$ & $1.33(0 \cdot 27)^{\star \star}$ \\
\hline $\begin{array}{l}\text { Tubular reabsorption of } \\
\text { calcium (mmol/1 GFR) }\end{array}$ & $1.03(0.06)$ & $0.78(0.05)^{\star \star}$ \\
\hline $\begin{array}{l}\text { Tubular reabsorption of } \\
\text { phosphate (mmol/l GFR) }\end{array}$ & $2.34(0.04)$ & $2 \cdot 70(0.08)^{\star \star}$ \\
\hline $\left.\begin{array}{rl}{ }^{\star} \mathrm{p} & <0.05 \\
\star \star \mathrm{p} & <0.02 \\
\star \star \star & <0.001\end{array}\right\}$ significant di & \multicolumn{2}{|c|}{\} significant difference between groups. } \\
\hline \multicolumn{2}{|c|}{$\begin{array}{l}\text { Hypercalcaemic: squamous lung } \\
\text { renal }\end{array}$} & $\begin{array}{l}=7 \\
=1\end{array}$ \\
\hline $\begin{array}{l}\text { Normocalcaemic: } \text { squamous } 1 \\
\text { adenocarci } \\
\text { small cell lu } \\
\text { breast } \\
\text { anaplastic }\end{array}$ & $\begin{array}{l}\text { lung } \\
\text { noma } \\
\text { ung }\end{array}$ & $\begin{array}{l}=11 \\
=5 \\
=1 \\
=1 \\
=1\end{array}$ \\
\hline
\end{tabular}

GFR = glomerular filtration rate. 
Table 2 Pattern of immunohistochemical staining for parathyroid hormone-related protein in normocalcaemic and hypercalcaemic groups

\begin{tabular}{lll}
\hline & $\begin{array}{l}\text { Normocalcaemic } \\
(n=19)\end{array}$ & $\begin{array}{l}\text { Hypercalcaemic } \\
(n=8)\end{array}$ \\
\hline Strongly positive & 11 & 8 \\
Weakly positive & 6 & 0 \\
Negative & $2^{\star}$ & 0 \\
\hline
\end{tabular}

*one breast carcinoma; one squamous carcinoma.

compared with $210.0(52.2) \mathrm{cm}^{3}$ (range 65.4 $523.6)$ in the hypercalcaemic patients $(\mathrm{p}<0.02)$. In nine normocalcaemic patients whose tumours were excised there was no significant change in serum calcium values (before surgery mean $(\mathrm{SEM})=2.52(0.01)$ $\mathrm{mmol} / \mathrm{l}$; after surgery $2.51(0.01) \mathrm{mmol} / \mathrm{l}$, $\mathrm{p}=\mathrm{NS}$ ). In contrast, serum calcium values fell significantly in five hypercalcaemic patients whose tumours were excised (before surgery = $3.02(0.09) \mathrm{mmol} / \mathrm{l}$; after surgery $=2.44(0.03)$ $\mathrm{mmol} / \mathrm{l}, \mathrm{p}<0.02)$.

Table 2 shows the pattern of immunohistochemical staining for parathyroid hormonerelated protein in normocalcaemic and hypercalcaemic patients. All eight of the tumours from hypercalcaemic patients stained strongly positively for the protein. Of the 19 tumours from normocalcaemic patients, $11(57 \%)$ stained strongly positive, six stained positive, and two negative $\left(\chi^{2}=4.78 ; p<0.05\right)$. In the normocalcaemic patients there was no apparent relation between the pattern of parathyroid hormone-related protein staining and subsequent development of hypercalcaemia; in 11 patients where detailed follow up checks of serum calcium concentration were performed, three became hypercalcaemic (two negative tumours, one positive tumour) and eight remained normocalcaemic (four strongly positive, four positive). All three of the normocalcaemic patients who subsequently became hypercalcaemic had biochemical evidence of parathyroid hormone-related protein-mediated hypercalcaemia when serum calcium values increased; all were hypophosphataemic and one (with an initially negatively staining tumour) was also found to have reduced values of tubular reabsorption of phosphate, raised values of tubular reabsorption of calcium, corrected for urinary sodium excretion, and very high cyclic AMP:creatinine concentrations.

\section{Discussion}

Biochemical evaluation of hypercalcaemic patients in this study showed features consistent with the actions of parathyroid hormonerelated protein on bone and kidney ${ }^{6-8}$; bone resorption, renal tubular reabsorption of calcium, and cyclic AMP excretion were all increased and serum phosphate and renal tubular reabsorption of phosphate reduced. These findings concur with previous clinical observations $^{9-11}$ and, along with the demonstration of parathyroid hormone-related protein in tumour tissue by immunostaining, emphasise the importance of the protein as the predominant humoral mediator of hypercalcaemia in malignancy. ${ }^{1-3}$

The increased cyclic AMP: creatinine values which we noted in four out of $19(21 \%)$ normocalcaemic patients confirm the findings

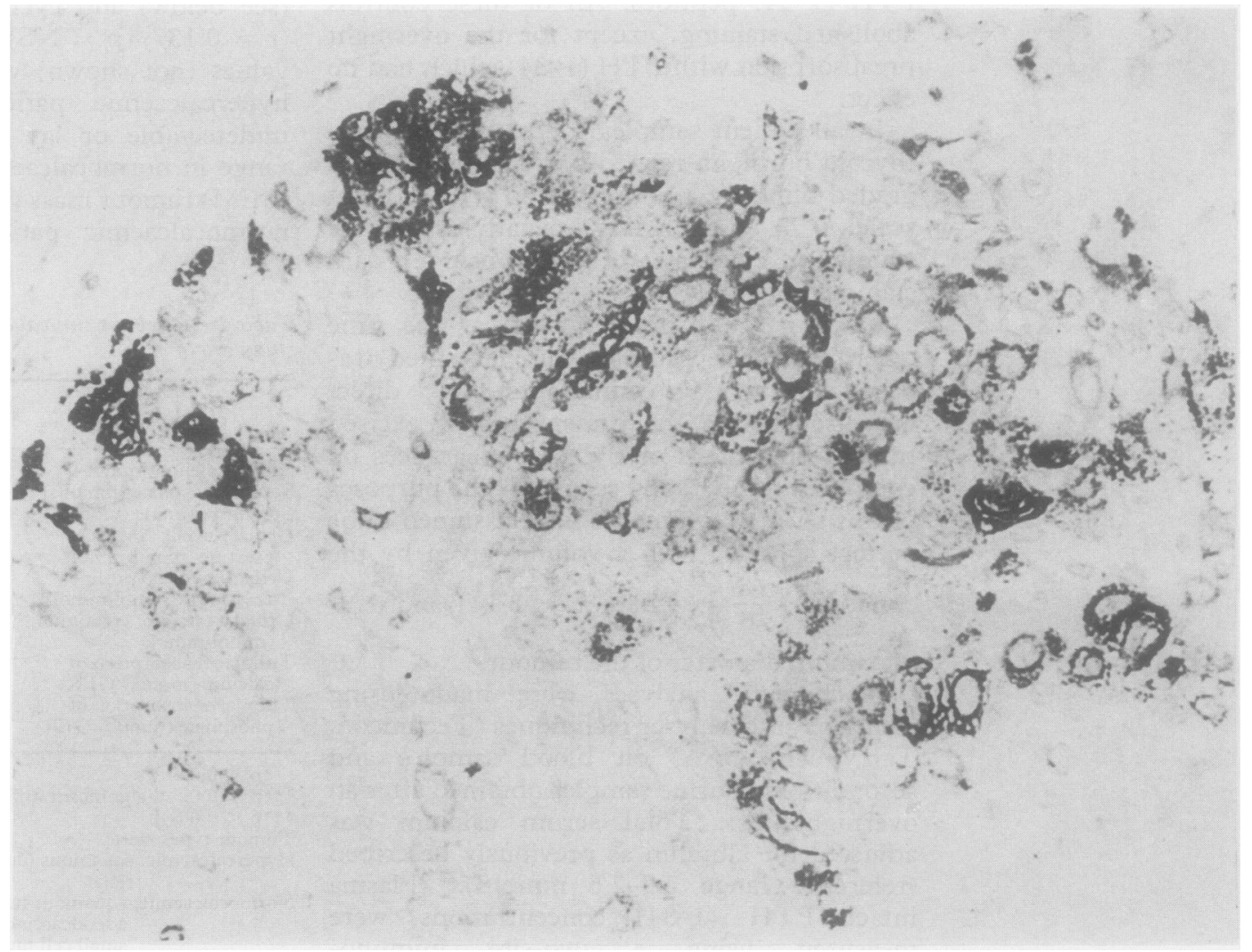


of previous workers ${ }^{25}$ and suggest that parathyroid hormone-related protein may also be released into the systemic circulation in normocalcaemic patients with cancer at concentrations which are presumably too low to cause a sustained increase in blood calcium activity. While measurement of plasma parathyroid hormone-related protein was not technically possible when our patients presented, it has been shown in a recent study that plasma concentrations may be increased in up to $25 \%$ of normocalcaemic cancer patients using a sensitive immunoradiometric assay. ${ }^{26}$

The present findings, together with previous immunohistochemical ${ }^{12}$ and in situ hybridisation data, ${ }^{14}$ show that parathyroid hormonerelated protein can be detected in tumours from both normocalcaemic and hypercalcaemic patients with cancer. Low tumour mass is an obvious explanation for the absence of hypercalcaemia in patients with positively staining tumours, and, indeed, tumour mass at the time of presentation was significantly lower in the normocalcaemic compared with the hypercalcaemic group. This is unlikely to have been the only factor in determining the occurrence of hypercalcaemia, however, as some normocalcaemic patients who exhibited positive or strongly positive staining for parathyroid hormone-related protein had tumours of equal size to those of the hypercalcaemic patients, and only one went on to develop hypercalcaemia despite progression of the tumours to a terminal stage.

Alternative explanations for the failure of such patients to develop hypercalcaemia include differences in the structure, biological effects, or rate of parathyroid hormone-related protein secretion between the normocalcaemic and hypercalcaemic subgroups. Several different types of parathyroid hormone-related protein with common amino terminal, but differing carboxyl-terminal, sequences may be generated as the result of differential splicing of the $3^{\prime}$ end of the messenger RNA. ${ }^{1327}$ Such differences may have existed in our patients, but would not have been detected by our antibody, in view of its amino-terminal specificity. While it is possible that these different forms of parathyroid hormone-related protein may have been processed in different ways or secreted at different rates, further studies on the molecular forms of the parathyroid hormone-related protein contained within the individual tumours, coupled with studies on intracellular processing and secretion of the peptide by cultured cell lines, would be needed to confirm whether this was the case. Although the possibility remains that the parathyroid hormone-related protein detected in tumour tissue from the normocalcaemic patients was not biologically active, this seems unlikely, given that the biological effects of parathyroid hormone-related protein (at least with regard to its renal tubular and bone resorbing effects) reside in the (1-34) portion of the molecule to which our antibody was directed..$^{1-3}$

A further explanation for differences in the degree of release of parathyroid hormonerelated protein by different tumours would be liberation of the protein from necrotic or ischaemic tissue. Such a mechanism is difficult to confirm or exclude, although with careful examination of excised tumour specimens and the histological sections used for immunohistochemistry, there seemed to be no difference in the degree of necrosis in tumours from normocalcaemic compared with hypercalcaemic patients.

The absence of parathyroid hormone-related protein in two squamous cell tumours from patients who subsequently developed biochemical evidence of mediated hypercalcaemia is puzzling, as we have previously reported identification of cytoplasmic parathyroid hormone-related protein in normal skin and in $100 \%$ of a series of squamous carcinomas from normocalcaemic patients. ${ }^{12}$ This most probably relates to technical factors such as loss of the antigen during fixation, although expression of parathyroid hormone-related protein in these patients at a later stage in tumour development, or selective parathyroid hormone-related protein expression in some but not all areas of tumour tissue, would also be possible. Unfortunately, however, we were unable to obtain further tissue in either case to investigate these possibilities.

1 Martin TJ, Suva LJ. Parathyroid hormone-related protein: a novel gene product. Clinical endocrinology and metabolism. Volume 2. London: Baillière-Tindall, 1988:1003-28.

2 Ralston SH. The pathogenesis of humoral hypercalcaemia of malignancy. Lancet 1987;ii:1443-6.

3 Broadus AE, Mangin NM, Insogna KL, Weir EC, Burtis WJ, Stewart AF. Humoral hypercalcaemia of malignancy: identification of a novel parathyroid hormone-like peptide. identification of a novel parathyr

4 Moseley JM, Kubota $M$, Diefenbach-Jagger $H$, et al. Parathyroid hormone-related protein purified from a human lung cancer cell line. Proc Natl Acad Sci USA 1987;84:5048-52.

5 Suva LJ, Winslow GA, Wettenhall REH, et al. A parathyroid hormone-related protein implicated in malignan hypercalcaemia: cloning and expression. Science 1987; 237:893-6.

6 Kemp BE, Moseley JM, Rodda CP, et al. Parathyroid hormone-related protein of malignancy: active synthetic fragments. Science 1987;238:1568-70.

7 Horiuchi N, Caulfield MP, Fisher JE, et al. Similarity of synthetic peptide from human tumor to parathyroid hormone in vivo and in vitro. Science 1987;238:1566-8.

8 Yates AJP, Guiterriez G, Smolens P, et al. Effects of a synthetic peptide of a parathyroid hormone-related protein on calcium homeostasis, renal tubular calcium protein on calcium homeostasis, renal tubular calcium reabsorption and bone metabolism in

9 Lafferty FW. Pseudohyperparathyroidism. Medicine $1906 ; 45: 247-60$

10 Stewart AF, Horst R, Deftos LJ, Cadman EC, Lang R, Broadus AE. Biochemical evaluation of patients with cancer-associated hypercalcaemia: evidence for humoral and non-humoral groups. N Engl J Med 1980;303: 1377-81.

11 Ralston SH, Fogelman I, Gardner MD, Dryburgh FJ, Cowan RA, Boyle IT. Hypercalcaemia of malignancy: evidence for a non-parathyroid agent with an effect on renal tubular handling of calcium. Clin Sci 1984;66:187-91.

12 Danks JA, Ebeling PR, Hayman J, et al. Parathyroid hormone-related protein of cancer: immunohistochemical localisation in cancers and in normal skin. J Bone Min Res 1989;4:273-8.

13 Ikeda K, Mangin M, Dreyer B, et al. Identification of transcripts encoding a parathyroid hormone-like peptide in messenger RNA's from a variety of human and animal tumours associated with humoral hypercalcaemia of malignancy. J Clin Invest 1988;81:2010-14.

14 Heath DA, Senior PV, Varley JM, Beck F. Parathyroid hormone-related protein in tumours associated with hypercalcaemia. Lancet 1990;335:66-9.

15 Rodda CP, Kubota M, Heath JA, et al. Evidence of a nove parathyroid hormone-related protein in fetal lamb parathyroid glands and sheep placenta: comparisons with a similar protein implicated in humoral hypercalcaemia of malignancy. $J$ Endocrinol 1988;117:261-71.

16 Loveridge N, Caple IW, Rodda CP, Martin TJ, Care AD. Evidence for a parathyroid hormone-related protein in fetal parathyroid glands of sheep. J Exp Physiol 1988; 73:781-4. 
17 Danks JA, Ebeling PR, Hayman JA, et al. Immunohistochemical localisation of parathyroid hormone-related protein in parathyroid adenoma and hyperplasia. $J$ Pathol 1990;161:27-33.

18 Thiede MA, Rodan GA. Expression of a calcium-mobilising parathyroid hormone-like peptide in lactating mammary tissue. Science 1988;242:278-80.

19 Meredino TJ, Insogna KL, Milstone LM, Broadus AE Stewart AF. A parathyroid hormone-like protein from

20 Ikeda K, Weir EC, Mangin M, et al. Expression of messenger ribinucleic acids encoding a parathyroid hormone-like peptide in human and animal tissues with abnormal expression in human parathyroid adenomas. Mol Endocrinol 1988;2:1230-6.

21 Mundy GR. Hypercalcaemia of malignancy revisited. J Clin Invest 1988;82:1-6.

22 Logue FC, Fraser WD, O'Reilly D St J, Beastall GH. The circadian rhythm of intact parathyroid hormone (1-84) and nephrogenous cyclic adenosine monophosphate in normal man. J Endocrinol 1989;121:R1-R3.
23 Bijvoet OLM. Indices for the measurement of the renal handling of phosphate. In: Massry SG, Fleisch H. eds. Renal handling of phosphate. New York: Plenum, 1980: $1-37$

24 Need AG, Guerin MG, Pain RW, Nordin BEC. The tubular maximum for calcium reabsorption: normal range and correction for sodium excretion. Clin Chim Acta 1985; 150:87-93.

25 Kukreja SC, Shemerdiak WP, Lad TE, Johnson PA. Elevated nephrogenous cyclic AMP with normal serum parathyroid hormone levels in patients with lung cancer. parathyroid hormone levels in patients
$J$ Clin Endocrinol Metab 1980;51:167-9.

26 Burtis WJ, Brady TG, Orloff JJ, et al. Immunochemical characterisation of circulating parathyroid hormonerelated protein in patients with humoral hypercalcaemia of cancer. N Engl J Med 1990;322:1106-12.

27 Thiede MA, Strewler GJ, Nissenson RA, Rosenblatt MA, Rodan GA. Human renal carcinoma expresses two messages encoding a parathyroid hormone-like peptide: evidence for the alternative splicing of a single copy gene. Proc Natl Acad Sci USA 1988;85:4605-9. 